\title{
COMPARISON AMONG BEANS SPECIES FOR FOOD SPROUTS YIELD
}

\section{COMPARAÇÃO ENTRE ESPÉCIES DE FEIJÃO UTILIZADAS PARA PRODUÇÃO DE BROTOS COMESTÍVEIS}

\author{
Joseli Viviane Ditzel NUNES ${ }^{1}$; Lúcia Helena Pereira NÓBREGA ${ }^{2}$; \\ Claudia Tatiana Araujo da CRUZ-SILVA ${ }^{3}$; Fábio Palczewski PACHECO ${ }^{4}$ \\ 1. Engenheira Agrônoma, Doutoranda, Programa de Pós-graduação em Engenharia Agrícola - PGEAGRI - Centro de Ciências Exatas e \\ Tecnológicas - CCET, Universidade Estadual do Oeste do Paraná - UNIOESTE, Cascavel, PR, Brasil, joselinunes@ yahoo.com.br; 2. \\ Engenheira Agrônoma, Professora, Doutora, PGEAGRI - CCET, UNIOESTE, Cascavel, PR, Brasil; 3. Bióloga, Doutoranda, PGEAGRI \\ - CCET, UNIOESTE, Cascavel, PR, Brasil; 4. Engenheiro Agrícola, Doutorando, PGEAGRI - CCET, UNIOESTE, Cascavel, PR, \\ Brasil.
}

\begin{abstract}
This study aimed at identifying beans species for food sprouts yield and comparing them according to physical, physiological, microbiological quality, chemical composition, as well as verifying their acceptability. Determinations of water content, germination, vigor and water uptake curve in seeds were carried out. Microbiological analyses, acidity, protein, iron, calcium and tannin were also recorded in the sprouts and acceptability was measured by sensorial analysis. The experimental design was completely randomized in a factorial scheme (4 X 4). The mung and cowpea beans seeds have shown the best physiological quality. The sprouts have shown microbiological quality in accordance with law. The mung beans have shown the highest sprout yield (695.32 g) and were six times higher than their initial mass. The sprout yield with common and cowpea beans species were not statistically significant; thus, it is necessary to study new methodologies. The highest protein $(21.17 \mathrm{~g})$ and iron contents $(9.25 \mathrm{mg})$ were observed in mung beans sprouts, while calcium $(360 \mathrm{mg})$ and tannin contents $(34.58 \%)$ were the highest in azuki beans sprouts. The mung and azuki beans sprouts have shown similar results in sensorial analysis and both showed good acceptability and satisfaction index above $70 \%$.
\end{abstract}

KEYWORDS: Nutrition. Seed germination. Sensorial analysis.

\section{INTRODUCTION}

The common beans (Phaseolus vulgaris L.) are one of the most important components in Brazilian diet. Therefore, they contain proteins, carbohydrates, vitamins, minerals, fiber, lysine and phenolic compounds with antioxidant action that reduce disease incidence (EMBRAPA, 2011b; MACHADO; FERRUZZI; NIELSEN, 2008). They can be both consumed as grains and in several cooking ways, such as savory; salty dishes, salads, cakes, cookies, sweets and ice cream, and also as sprouted seeds (MACHADO et al. 2009; EMBRAPA, 2011a).

The germination stadium is the richest in nutrients throughout plant development. They are mostly easy digested and assimilated by the organism. So, its stadium is related to a predigestive process in which proteins are decomposed into amino acids, fats into fatty acids and complex carbohydrates into simple sugars (MAYER; POLJAKOFF-MAYBER， 1989; CARVALHO; NAKAGAWA, 2000).

In China, Japan and the United States, human consumption of sprouted seeds, called sprouts, is widespread and appreciated. In Brazil, there is a growing demand and consumption of such food (DUQUE et al., 1987; VIEIRA; NISHIHARA, 1992).

The mung beans (Vigna radiata L.) are the most used species for this process and with their germination, beans sprouts, known as moyashi, are obtained (MACHADO et al., 2009). Studies with sunflower, alfalfa, lentils and mung beans sprouts showed that nutrients content such as protein, iron and vitamin $\mathrm{C}$ in these foods are increasing due to germination (MERCALI, 2011; VIEIRA; LOPES, 2001; LOURES, NÓBREGA, COELHO, 2009; MACHADO et al., 2009).

The physiological seed quality is related to its ability on performing vital functions, characterized by longevity, germination and vigor. Thus, if the seed has no quality, there is a decrease in germination percentage, abnormal seedling increase and seedling vigor reduction (TOLEDO et al., 2009).

Therefore, high quality seeds are not only essential for the appropriate crop establishment, but also for sprouts yield. Some quality components must be considered such as seeds with high pureness, right water content, color and size uniformity, ability to generate a perfect and vigorous plant and, finally, it should have good health quality (ARAUJO et al., 2011; VIEIRA; LOPES, 2001). 
Chitarra and Chitarra (2005) claimed that in natura food is classified mainly by sensorial, shape and size attributes. The affective tests are important tools since they quickly show the straight consumer's opinion or the product potential on their specific features or general idea about them. They measure how someone liked or disliked a particular product, evaluating preference or acceptability (FERREIRA et al., 2000).

Based on this context, this study aimed at identifying beans species for food sprouts yield and comparing them according to physical, physiological, microbiological quality, chemical composition, as well as verifying their acceptability as an alternative food to add nutritional values.

\section{MATERIAL AND METHODS}

Untreated seeds of mung beans (Vigna radiata L.), azuki beans (Vigna angularis (Willd) Ohwi \& Ohashi), cowpea (Vigna unguiculata (L.) Walp) and common beans (Phaseolus vulgaris L. var. Carioca) were put in paper bags and stored under $7{ }^{\circ} \mathrm{C}$ for pest prevention during the experimental term. The analyses were carried out at the Seeds and Plants Evaluation Laboratory, Quality Control of Agricultural Products Laboratory and Laboratory of Water and Food Microbiological Control, from Western Paraná State University, in Campus of Cascavel.

The evaluation of 100 seeds weight, moisture content, germination (normal seedlings) (BRASIL, 2009), emergence speed index - ESI (MAGUIRE, 1962), emergence speed - ES (EDMOND; DRAPALA, 1958) and water uptake curve (NÓBREGA, 1993) were recorded to determine physical and physiological seeds quality.

Vieira and Lopes (2001) methodology was adopted in this trial to sprouts yield, in order to produce mung beans sprouts. After washing them with drinking water, the seeds were sterilized with sodium hypochlorite at $0.5 \%$ for two minutes, then rinsed and immersed in water for approximately 12 hours until doubled in volume. They were transferred to adapted containers to help on their growth (plastic containers were perforated at the bottom, covered and wrapped with an aluminum foil), watered at almost $20^{\circ} \mathrm{C}$ every 6 to 8 hours.

The sprouts yield was carried out in a germination chamber at $23{ }^{\circ} \mathrm{C}$ average for better development. The growth containers were wrapped with aluminum foil, since light is a limiting factor for the sprouts, which can get greenish, hard and etiolated when they receive light.
After 24 hours, weights of approximately 6 $\mathrm{g} \mathrm{cm}^{-2}$ were placed on seeds using write stones in transparent plastic bags to cause essential physiological stress, increase sprout hypocotyl and reduce root length.

The crop was harvested on the $5^{\text {th }}$ day, then, sprouts were removed from growth container and transferred to containers that were five times larger their water volume. The seed coat was eliminated by stirring in water, to avoid unpleasant taste, and to get a good aspect and a long postharvest shelf life time.

Microbiological analyses were carried out in freshly harvested sprouts to count total and fecal coliforms and Salmonella sp., according to the methodology proposed by MAPA - Ministry of Agriculture, Livestock and Supply (BRASIL, 2003b).

After harvesting, the sprouts were weighed to obtain the yield. As the productions, since the sprout common and cowpea beans were not significant, the following analyses were performed by mung and azuki beans sprouts.

The studied physical-chemical parameters were: acidity determination (INSTITUTO ADOLFO LUTZ, 2008), protein content (micro-Kjedahl method, using 6.25 as conversion factor from nitrogen in protein). Tannin determination was recorded according to the spectrophotometry modified by Folin-Ciocalteau to obtain the results expressed in $\mathrm{g}$ phenol (tannic acid) $\mathrm{g}^{-1} \mathrm{~ms}^{-1}$ (HORWITZ, 1995). Minerals ( $\mathrm{Ca}$ and $\mathrm{Fe}$ ) were determined according to MAPA methodology (BRASIL, 1991). Iron and calcium results were determined by dry matter and expressed in $100 \mathrm{mg} \mathrm{g}^{-1}$.

Sensorial analysis was obtained in mung and azuki beans sprouts. The acceptance test was applied using hedonic scale of nine points $(9=$ liked very much, 1 = disliked very much) according to Meilgaard et al. (1999), with 40 non-trained panelists (public workers, professors and students from the University). The acceptance index was calculated to evaluate beans sprouts acceptability as in natura food stuff (DUTCOSKY, 2011).

Two fresh beans sprouts samples were presented in white dishes encoded with three-digit numbers and distributed on a bench for panelists' evaluation (STONE; SIDEL, 1993). Each taster received water in plastic cups in order to remove any residue from previous tries and to make the evaluation easier. Samples were randomized distributed and underwent change in position for each of the panelists, who tasted samples one by one. They noted their evaluation with extra 
information when necessary. The acceptance index was calculated as an expression average percentage of satisfaction level based on their acceptance level.

The experimental design was completely randomized (RED) with four replications for each tested variety. The treatment averages were compared by Tukey test at 5\% probability. Analyses of variance and average tests were obtained according by Sisvar ${ }^{\circledR}$ software, version 5.3 (FERREIRA, 2008).

\section{RESULTS AND DISCUSSION}

Physical characterization of mung, azuki, cowpea and common beans seeds is given by 100 seeds weight values and water content, described on Table 1.

Table 1. Averages levels of 100 seeds weight values and water content of mung, azuki, cowpea and common beans seeds.

\begin{tabular}{lcc}
\hline Beans & 100 seeds weight $(\mathbf{g})$ & Water content $(\boldsymbol{\%})$ \\
\hline Mung & $4.48 \mathrm{~d}$ & $9.7 \mathrm{c}$ \\
Azuki & $7.65 \mathrm{c}$ & $9.7 \mathrm{c}$ \\
Cowpea & $17.48 \mathrm{~b}$ & $10.9 \mathrm{~b}$ \\
Common & $20.09 \mathrm{a}$ & $11.6 \mathrm{a}$ \\
\hline CV $(\%)$ & 1.34 & 1.40 \\
General average & 12.42 & 10.5 \\
\hline
\end{tabular}

Averages followed by the same letter in the column do not differ by Tukey test at 5\% probability. The obtained data came from the original observations and are followed by the letters obtained when comparing averages transformed in $\sqrt{x}$.

The mung beans, followed by azuki beans, presented the lowest answers of 100 seeds weight. Vieira et al. (2011) obtained $5.0 \mathrm{~g}$ of 100 seeds weight for Ouro Verde MG-2 of mung beans variety, in accordance with this trial. The common beans showed the highest average of 100 seeds weight. A superior average was obtained by Coelho et al. (2010) (24.72 g) for IPR 81 common beans.

According Loures, Nóbrega and Coelho (2009), there may be changes in 100 seeds weight depending on seed water content, dry matter accumulation as well as the environmental conditions of the yield area. It is observed that the evaluated species showed significant difference in 100 seeds weight and this is due to the diversity of Fabaceae family, which can be divided into size, weight, thickness and color (EMBRAPA 2011b ; UNIFEIJÃO 2011).

Common bean seeds showed the highest water content percentage, which was low when compared to values from Brazilian Table of Food Composition (TACO, 2011), which is $14 \%$ for crude common beans.

Azuki and mung beans showed similar values of water content $(9.7 \%)$, so they did not differ statistically among themselves. Araujo (2011) observed higher water content values for mung beans seeds (11\% moisture). Machado et al. (2009) registered inferior values, in which mung beans seeds showed $7.9 \%$ moisture.

The seed water content was not proportional to its weight, because the seed species with the smallest weight showed values very close to the water content of other tested species, confirming the influence of forecast conditions.

The percentage of normal seedlings (germination), emergence speed index (ESI) and emergence speed (ES) of the studied beans species are shown on Table 2.

Mung beans showed the highest normal seedlings (germination) percentage $(94 \%)$. This trial obtained similar results to Vieira et al. (2011), who studied six seed lots of mung beans germination percentage and recorded answers above 90\%. Caldas (2004) also observed that the germination values of eight strains of mung beans ranged from 89 to $98 \%$, and highlighted that the standard germination test, carried out under optimal room conditions of temperature, moisture and light, can result in maximum seed germination potential in accordance with what was observed in this study.

Azuki beans showed the lowest germination percentage (82\%). All species showed values above $80 \%$ germination, required for trading as seeds, according to the "Secretaria da Agricultura e do Abastecimento" - BRASIL (1986) and BRASIL (2003a), so, there were a low percentage of abnormal seedlings and dead seeds.

The highest answers concerning ESI were observed on mung and cowpea beans, since they were more vigorous. Azuki beans showed the least vigor. Mung, cowpea and common beans showed similar answers regarding ES, whose azuki beans had the highest value.

Ludwig et al. (2008) observed that beans seeds with the best physiological quality showed the 
highest answers of cropping emergence, ESI, plants high, leaf area and dry weight per plant during the initial growth period.

Even though azuki beans have shown different results when compared to the other studied species, the ES answers were similar among them. In relation to the average seed weight, seeds with
NUNES, J. V. D. et al.

the highest results did not seen to be more vigorous than the others. For example, mung beans seeds $(44.78 \mathrm{~g})$ showed $10.15 \mathrm{ES}$, so, they were lighter than the common beans (200.92 g) with the highest ES (10.24).

Table 2. Normal seedlings, emergence speed index (ESI) and emergence speed (ES) of mung, azuki, cowpea and common seedling beans.

\begin{tabular}{lccc}
\hline Beans & Normal Seedlings & ESI & ES \\
\hline & $(\%)$ & & (Days) \\
\hline Mung & $94 \mathrm{a}$ & $44.29 \mathrm{a}$ & $10.15 \mathrm{~b}$ \\
Azuki & $82 \mathrm{~b}$ & $25.93 \mathrm{c}$ & $11.27 \mathrm{a}$ \\
Cowpea & $87 \mathrm{ab}$ & $45.21 \mathrm{a}$ & $10.09 \mathrm{~b}$ \\
Common beans & $83 \mathrm{~b}$ & $38.64 \mathrm{~b}$ & $10.24 \mathrm{~b}$ \\
\hline CV $(\%)$ & 7.05 & 5.84 & 0.93 \\
General Average & 87 & 38.52 & 10.44 \\
\hline
\end{tabular}

Averages followed by the same letter in the column do not differ by Tukey test at 5\% probability. The data were obtained from the original observations and followed by the obtained letters when comparing averages in percentage transformed in arc sin $\sqrt{\frac{x}{100}}$.

When the ESI was compared to the normal seedling percentage, it could be observed that mung and cowpea beans presented the highest germination percentage and vigor. Even though, azuki and common beans seeds showed germination percentage over $80 \%$, they were less vigorous than the others.

In general, water uptake was faster during the 10 first hours, followed by a decrease on it until
36 hours and absorption with an increase until 48 hours. Thus, it got adjusted to the triphasic pattern. According Bewley and Black (1994), the seed imbibition process is characterized by an initial fast water uptake, then, a stationary phase in which the seeds almost do not absorb water and finally a further increase in water uptake curve, which coincides with radicle protrusion and seedling growth (Figure 1).

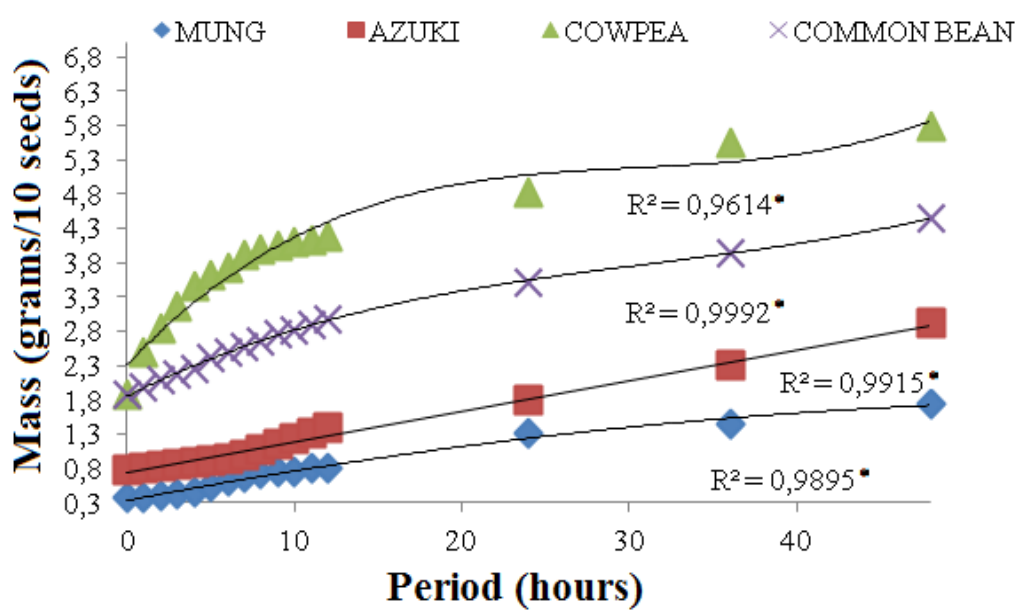

Figure 1. Water uptake by mung, azuki, cowpea and common beans seeds during 48 hours. The $\mathrm{R}^{2}$ values followed by * are significant at $5 \%$ probability.

Cowpea beans showed fast imbibition whose water uptake was $59 \%$ during the 12 first hours. Campos et al. (2010) studied five cowpea varieties and found out that the UFRR Grão Verde variety spent 5 hours and 12 minutes to double the volume. These results reinforce that cowpea beans absorb water very quickly.

During the 12 first hours, cowpea and common beans seeds showed faster imbibition than the others. This may have been due to the larger contact area of the seeds, as these two species had 
higher 100 seeds weight. Similar results were found out by Amaral et al. (2012) when studied bulk classes of canola seed. Mung and azuki varieties showed the slowest uptake during the 12 first hours, with 33 and $29 \%$, respectively.
The seeds kept on absorbing water until the last weighing (48h), which was slower than the 12 first hours. The cowpea beans absorbed more water throughout the period, followed by common, azuki and mung beans, respectively. Production data were obtained after sprouts yield (Table 3 ).

Table 3. Average yield values of mung, azuki, common and cowpea beans sprouts.

\begin{tabular}{lc}
\hline Beans & yield (g sprouts 100 g seeds) \\
\hline Mung & $695.32 \mathrm{a}$ \\
Azuki & $114.12 \mathrm{~b}$ \\
Cowpea & $0 \mathrm{c}$ \\
Common & $16.6 \mathrm{c}$ \\
\hline CV $(\%)$ & 7.87 \\
General Average & 51.63 \\
\hline Averages followed by the same letter in the column do not differ by Tukey test at $5 \%$ probability.
\end{tabular}

Mung beans showed the highest yield

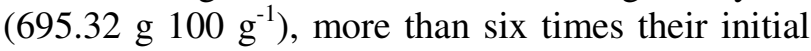
weight. In accordance with these results, Vieira e Lopes (2001) justify that $1 \mathrm{~kg}$ of small seeds such as mung beans can produce $5-7 \mathrm{~kg}$ sprouts, which means 500-700 g sprouts per 100 seeds.

Azuki beans showed low yield (114.12 g $\left.100 \mathrm{~g}^{-1}\right)$ and this could have happened due to the physiological quality of these seeds, because although it had shown $82 \%$ germination, there was the lowest vigor when compared to the other evaluated species.

Common beans showed the lowest yield (16 $\mathrm{g}$ sprouts per $100 \mathrm{~g}$ seeds), which is not appropriate to sprout yield. This may have occurred because the seeds were not so vigorous, as it can be seen when ESI was obtained. It can also be highlighted that the applied methodology is not specific for such specie, so it was adopted from VIEIRA e LOPES (2001) to mung beans.
Although cowpea beans did not show sprout results when submitted to the same process of sprouts production as the other species were, it was statistically equal to common beans. This specie absorbed the most amount of water in the shortest time as it can be observed on the water curve results. Here, at the first 12 hours, cowpea beans absorbed twice more water than its initial weight. When the imbibition process is very fast, it can be presumed that the quality seed is poor, since the deterioration process causes the imbibition speeding.

The following evaluations were carried out only with mung and azuki beans species, which there was a significant sprout yield.

Microbiological analyses values for mung and azuki sprouts are on Table 4. Total coliforms results were more than $2.400 \times 10^{3} \mathrm{MPN} \mathrm{g}^{-1}$, according to the established patterns by legislation.

Table 4. Results of microbiological analyses in mung and azuki sprouts beans, for total coliforms counting at $35^{\circ} \mathrm{C}$, Thermotolerant at $45^{\circ} \mathrm{C}$ and Salmonella sp research.

\begin{tabular}{lccc}
\hline Sprouts & $\begin{array}{c}\text { Total Coliforms } \\
\text { to } 35^{\mathbf{0}} \mathbf{C} \\
\left(\mathbf{M P N ~}^{-\mathbf{1}}\right)\end{array}$ & $\begin{array}{c}\text { thermotolerant Coliforms to 45 } \\
\mathbf{o}_{\mathbf{C}} \\
\left(\mathbf{M P N ~}^{-\mathbf{1}}\right)\end{array}$ & $\begin{array}{c}\text { Salmonella } \text { sp. } \\
\text { absence/ } \\
\text { presence }\end{array}$ \\
\hline Mung I & $>2.400 \times 10^{3}$ & $<3$ & Absence \\
Azuki II & $>2.400 \times 10^{3}$ & $<3$ & Absence \\
Mung I $^{*}$ & $>2.400 \times 10^{3}$ & $<3$ & Absence \\
Azuki II $^{*}$ & $>2.400 \times 10^{3}$ & $<3$ & Absence \\
\hline
\end{tabular}

$\mathrm{MPN} \mathrm{g}^{-1}$ - the most probable number per gram. I, $\mathrm{II}^{*}=$ repetition.

Loures, Nóbrega and Coelho (2009), when produced lentil sprouts, obtained superior answers than $1.1 \times 10^{2}$ MPN $g^{-1}$ for total and fecal coliforms, which indicates contamination. For both beans sprouts, the answers were less than $3 \mathrm{MPN} \mathrm{g}^{-1}$ for fecal coliform. In lentil sprouts, Loures, Nóbrega and Coelho (2009) observed that Escherichia coli growth was below $10 \mathrm{UFC} \mathrm{g}^{-1}$, similar to this trial. This could mean the coliform that showed some growth can be from other strains, i.e., Enterobacter sp. or Klebsiella sp., but not necessarily Escherichia coli (SILVA Et al. 2007). 
The coliforms research in food indicates sanitary and hygiene qualities. Coliforms are enterbacteria group that are present in feces and environment such as soil, surface plant, animals and utensils (FRANCO; LANDGRAF, 2007), and can cause several physiological disorders as abdominal pain, vomiting, fever, diarrhea, gastroenteritis in children, nausea, among others (LOPES, 2007).

There was no growth in Salmonella sp. research for mung and azuki beans sprouts, but absence, as the resolution recommends. Similar results were observed by Loures, Nóbrega and Coelho (2009) with lentil sprouts.
According to Jay (2005), the natural or inherent acidity of foods, especially fruits, could contribute to the protection against microorganism attack, i.e., the lowest obtained $\mathrm{pH}$ for some bacteria growth is 4.5 for E. coli and 4.05 for Salmonella. As the acidity percentage values were 3.1 and $2.3 \%$ for mung and azuki beans sprouts, respectively, this may have not helped microorganisms' development.

Mung and azuki beans sprouts showed 3.1\% and $2.3 \%$ acidity, respectively (Table 5). Loures, Nóbrega and Coelho (2009) recorded values near those ones $(2.64 \%)$ when determined acidity in lentil sprouts.

Table 5. Values of acidity, protein, calcium, iron and tannin in 100 grams of mung and azuki beans sprouts.

\begin{tabular}{lccccc}
\hline Sprouts & $\begin{array}{c}\text { Acidity } \\
(\boldsymbol{\%})\end{array}$ & $\begin{array}{c}\text { Protein } \\
(\mathbf{g})\end{array}$ & $\begin{array}{c}\mathbf{C a} \\
(\mathbf{m g})\end{array}$ & $\begin{array}{c}\text { Fe } \\
(\mathbf{m g})\end{array}$ & $\begin{array}{c}\text { Tannin } \\
(\boldsymbol{\%})\end{array}$ \\
\hline Mung & $3.1 \mathrm{a}$ & $21.17 \mathrm{a}$ & $120.0 \mathrm{~b}$ & $9.25 \mathrm{a}$ & $30.69 \mathrm{~b}$ \\
Azuki & $2.3 \mathrm{a}$ & $17.81 \mathrm{~b}$ & $360.0 \mathrm{a}$ & $6.0 \mathrm{~b}$ & $34.58 \mathrm{a}$ \\
\hline CV $(\%)$ & 23.96 & 6.52 & 0 & 4.64 & 6.75 \\
General average & 2.7 & 19.49 & 240.0 & 7.63 & 32.64 \\
\hline
\end{tabular}

The means followed by the same letter in the column do not differ themselves significantly by Tukey test at $5 \%$ probability.

Mung beans showed the highest percentage of organic acids and can be considered acid, which may justify the bacteria absence, observed in microbiological analyses.

The highest protein content was observed in mung beans sprouts $(21.17 \mathrm{~g})$, showing that it is better to consume those ones than azuki beans sprouts (17.81 g protein content). Machado et al. (2009) observed protein values of $36.70 \mathrm{~g}$ in mung beans sprouts, near to the commercial protein values

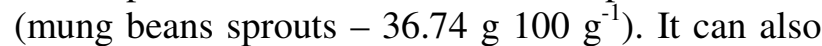
be observed that the grain protein value $(29.22 \mathrm{~g})$ is lower than in the bud.

Azuki beans sprouts showed the highest calcium contents (360 mg $100 \mathrm{~g} \mathrm{~g}^{-1}$ ). Veloso (2012) obtained similar results and an increase answer of this nutrient during germination. On the other hand, mung beans sprouts showed $120 \mathrm{mg}$ calcium $100 \mathrm{~g}$ 1. Machado et al. (2009) have also obtained increased calcium content during germination, while in grain, this content was $121.67 \mathrm{mg}$ and in the fifth day of germination, the sprout content was $130.0 \mathrm{mg}$ $100 \mathrm{~g}^{-1}$.

Mung beans sprouts showed higher iron content than azuki. Machado et al. (2009) observed lower values for iron $\left(5.36 \mathrm{mg} 100 \mathrm{~g}^{-1}\right.$ mung beans sprouts) after five days of germination.

Azuki beans sprouts showed higher tannin contents than mung. Therefore, substances as tannins and phytates in foods inhibit the absorption of calcium, zinc, iron and protein (FPA, 2009).
Thus, this justified some concern about high tannin contents presented in the studies sprouts and it may have been high due to the seed storage period until the conclusion of all tests.

Ramirez-Cardenasi et al. (2008) found out that in five beans varieties, the tannin amount was different. These authors have also observed less tannin amount $\left(33.38 \mathrm{mg} 100 \mathrm{~g}^{-1}\right.$ of catechin in Ouro Branco variety) as well as higher tannin levels (182.60 mg $100 \mathrm{~g}^{-1}$ of catechin in BRS Radiante variety).

In sensorial analysis, mung bean and azuki sprouts received the highest score for texture, followed by size and appearance parameters (Table 6). According to the use hedonic scale, these attributes ranged from 7.30 to 7.0 , so, they fit the following category: "I liked it moderately". The flavor for both sprouts showed the lowest score. This can be because sprouts have an acid natural flavor without additions of any seasoning. In relation to flavor, the sprouts have reached 6.44 as general average for hedonic scale (I liked slightly). This answers showed that, on average, the panelists enjoyed the sprouts.

The mung beans sprouts showed, in general evaluation, the highest average; probably due to its close relation concerning the commercial sprout flavor. The azuki beans sprouts were not inferior to mung beans, so they were considered acceptable for human consumption. 
Table 6. Averages of sensorial analysis attributes: appearance, size, shape, color, odor, texture, flavor, general evaluation and satisfaction index of mung and adzuki beans sprouts.

\begin{tabular}{lcccc}
\hline Attributes & Mung & Azuki & Average & Satisfaction index (\%) \\
\hline Appearance & $7.00 \mathrm{a}$ & $6.78 \mathrm{a}$ & 6.89 & 76.56 \\
Size & $7.10 \mathrm{a}$ & $6.90 \mathrm{a}$ & 7.00 & 77.78 \\
Shape & $6.80 \mathrm{a}$ & $6.53 \mathrm{a}$ & 6.66 & 74.00 \\
Color & $6.80 \mathrm{a}$ & $6.35 \mathrm{a}$ & 6.58 & 73.10 \\
Odor & $6.50 \mathrm{a}$ & $6.55 \mathrm{a}$ & 6.53 & 72.56 \\
Texture & $7.30 \mathrm{a}$ & $6.93 \mathrm{a}$ & 7.11 & 79.00 \\
Flavor & $6.58 \mathrm{a}$ & $6.30 \mathrm{a}$ & 6.44 & 71.56 \\
General evaluation & $6.83 \mathrm{a}$ & $6.59 \mathrm{a}$ & 6.71 & 74.56 \\
\hline General average & 6.86 & 6.62 & & 74.89 \\
\hline
\end{tabular}

Averages followed by the same letter in the row do not differ by themselves according to Tukey test at $5 \%$ probability.

The sensorial attributes of appearance, color and flavor, beans sprouts received the highest scores during 72-hour of germination period when compared to 96-hour one, since the last ones had shown a greenish color and strong bitter taste (MARTINEZ et al., 2011),

Some possible factors for greenish sprouts are chlorophyll synthesis and concentration by light exposure. This exposure can also lead to the glycoalkaloids concentration, which, when in high concentration, produces some bitter taste (KRAUTLER, 2003; ROCA et al., 2004). This may have happened to the analyzed sprouts in this study, because they were greenish and bitter, even though the light exposure has been avoided during their yield as recommended (VIEIRA; LOPES, 2001).

The texture was the most appreciated attribute with $79 \%$ satisfaction index. The flavor showed the lowest satisfaction index $(71.56 \%)$. All attributes were above $79 \%$ satisfaction index. According to Dutcosky (2011), these sprouts would be well accepted by the consumer as well as available for commercial production.

The mung and azuki beans sprouts showed good satisfaction index (74.89\%). Such results were close to the satisfaction index observed for lentil sprouts $(67 \%)$, mung beans sprouts $(78.11 \%)$ and alfalfa sprouts $(78.11 \%)$ (Loures, Nóbrega and Coelho, 2009).

\section{CONCLUSIONS}

The mung and cowpea beans species showed the best physiological seed quality. However, the sprouts yield was only possible for mung and azuki beans species. Thus, common and cowpea beans species required some adaptation of methodologies for sprouts yield.

The sprouts showed microbiological quality with total coliforms and Escherichia coli values inferior the answers already recommended by the standard regulation. Also, it was not observed the presence of Salmonella sp.

According to the nutritional point of view, mung beans sprouts, with the highest contents of protein and iron, are the most indicated for human consumption. The mung and azuki beans sprouts were similar based on acceptability, with satisfaction index above $70 \%$.

RESUMO: O objetivo deste trabalho foi identificar espécies de feijão utilizadas para a produção de brotos alimentícios e compara-las quanto à qualidade física, fisiológica, microbiológica e sua composição química, bem como verificar a aceitabilidade destes. Nas sementes foram realizadas determinações de teor de água, germinação, vigor e curva de absorção de água. Nos brotos, foram realizadas análises microbiológicas, acidez, proteína, ferro, cálcio, tanino. A aceitabilidade por análise sensorial. O delineamento foi inteiramente casualizado (4 X 4). As sementes do feijão mungo e do feijão caupi demonstraram melhor qualidade fisiológica. Os brotos apresentaram valores em conformidade com a legislação. O feijão mungo apresentou maior produtividade (695,32 g de broto), com produção referente a seis vezes de sua massa inicial. A produção de brotos com a espécie carioca e caupi não foi significativa, sendo necessário o estudo de novas metodologias. Maiores teores de proteína $(21,17 \mathrm{~g})$ e ferro $(9,25 \mathrm{mg})$ foram observados nos brotos de mungo, enquanto que os teores de cálcio $(360 \mathrm{mg})$ e tanino $(34,58 \%)$ foram maiores nos brotos de feijão azuki. Os brotos de feijão mungo e azuki apresentaram resultados semelhantes na análise sensorial, e mostraram boa aceitabilidade, com índice de satisfação acima de $70 \%$.

PALAVRAS-CHAVE: Análise sensorial. Germinação de sementes. Nutrição. 


\section{REFERENCES}

AMARAL, A. D. ; MEDEIROS, S. L. P.; MENEZES, N. L.; LUZ, G. L. da; PIVOTO, D.; BIALOZOR, A. Qualidade de sementes de canola classificadas por densidade. Revista Brasileira de Sementes, Londrina, v. 34, n. 2, p. 302-309, 2012. http://dx.doi.org/10.1590/S0101-31222012000200016

ARAUJO, R. F.; ZONTA, J. B.; ARAÚJO, E. F.; HEBERLE, E.; ZONTA, F. M. G. Teste de condutividade elétrica para sementes de feijão-mungo-verde. Revista Brasileira de Sementes, Londrina, v. 33, n. 1, p. 123130, 2011.

BEWLEY, J. D.; BLACK, M. Seeds: physiology of development and germination. New York: Plenum Press, 1994. 445 p. http://dx.doi.org/10.1007/978-1-4899-1002-8

BRASIL. Legislação brasileira sobre sementes e mudas. Lei $n^{\circ} 10.711$, Decreto ${ }^{\circ} 5.153$, de 23 de julho de 2004. Diário Oficial da União, Brasília, Seção 1, p.1, 05 de agosto de 2003a.

BRASIL. Ministério da Agricultura, Pecuária e Abastecimento. Instrução normativa n. 62 de 26 de agosto de 2003. Diário Oficial da União, Brasília, 22 de setembro de 2003b.

BRASIL. Ministério da Agricultura, Pecuária e Abastecimento. Métodos analíticos para controle de alimentos. Portaria ${ }^{\circ} 108$ de 4 de setembro de 1991.

BRASIL. Ministério da Agricultura, Pecuária e Abastecimento. Regras para análise de sementes / Ministério da Agricultura, Pecuária e Abastecimento. Secretaria de Defesa Agropecuária. - Brasília: Mapa/ACS, 2009. $399 \mathrm{p}$.

BRASIL. Secretaria de Estado da Agricultura e do Abastecimento. Resolução no 051, de 18 de dezembro de 1986. Adota e aprova para Produção de Sementes Básicas, Registradas, Certificadas e Fiscalizadas pela Resolução n ${ }^{\circ} 02$ de 08.12.1986 da CESM/Pr. Curitiba, 1986.

CALDAS, M. T. Qualidade fisiológica de sementes e brotos de feijão-mungo-verde. Viçosa: UFV, 2004. 58 p. Dissertação (Mestrado em Fitotecnia) - Universidade Federal de Viçosa, Viçosa, 2004.

CAMPOS, E. S.; ALVES, J. M. A.; UCHÔA, S. C. P.; ALBUQUERQUE, E. A. A. SANTOS, C. S. V. Características morfológicas e físicas de grãos secos e hidratados de cinco cultivares de feijão-caupi. Revista Agroambiente, Boa Vista, v. 4, n. 1, p. 34-41, 2010.

CARVALHO, N. M.; NAKAGAWA, J. Sementes: Ciência, tecnologia e produção. Jaboticabal: FUNEP, 2000. $588 \mathrm{p}$.

CHITARRA, M. I. F.; CHITARRA, A. B. Pós-colheita de frutas e hortaliças: Fisiologia e manuseio. Lavras: FAEPE, 2005. 785 p.

COELHO, C. M. M.; MOTA, M. R.; SOUZA, C. A.; MIQUELLUTI, D. J. Potencial fisiológico em sementes de cultivares de feijão crioulo (Phaseolus vulgaris L.). Revista Brasileira de Sementes, Londrina, v. 32, n. 3, p. 97-105, 2010.

DUQUE, F. F.; SOUTO, S. M.; ABBOUD, A. C. Mungo, proteína em forma de broto de feijão. A Lavoura, Rio de Janeiro, v. 90, p. 21-23, 1987.

DUTCOSKI, S. D. Análise sensorial de alimentos. $3^{\mathrm{a}}$ ed. Curitiba: Champagnat. 2011.

EDMOND, J. B.; DRAPALA, W. J. The effects of temperature, sand and soil, and acetone on germination of okra seeds. Proceedings of American Society of Horticultural Science, Alexandria, v. 71, n. 2, p. 428-434, 1958. 
EMBRAPA. Embrapa Arroz e Feijão. Sistemas de produção. Disponível em:

<sistemasdeproducao.cnptia.embrapa.br/.../Feijao/FeijaoPrimSegSafraS...> Acesso em: 26 dez. 2011a.

EMBRAPA. Delícias com arroz e feijão. Disponível em:

$<$ livraria.sct.embrapa.br/liv_resumos/pdf/00062270.pdf>. Acesso em 29 dez. 2011.b

FEDERAÇÃO PAULISTA DE ATLETISMO - FPA. Fatores antinutricionais. Disponível em:<muitoalemdecomida.com/2009/.../fatores-antinutricionais.ht..>. Acesso em 07 nov. 2012.

FERREIRA, D. F. SISVAR: um programa para análises e ensino de estatística. Revista Científica Symposium, Lavras, v.6, n.2, p. 36-41, 2008.

FERREIRA, V. L. P.; ALMEIDA, T. C. A.; PETTINELli, M. L. C. V.; SILVA, M. A. A. P.; CHAVES, J. B. P.; BARBOSA, E. M. M. Análise sensorial: Testes discriminativos e afetivos. Campinas, SBCTA, 2000. 127 p.

FRANCO, B. D. G. M.; LANDGRAF, M. Microbiologia de alimentos, $2^{\mathrm{a}}$ ed. São Paulo: Editora Atheneu, 2007. $182 \mathrm{p}$.

HORTWITZ, H. Official method of analysis of the Association of Official Agricultural Chemistry. 8 ed. Washington: AOAC, 1995. 144 p.

INSTITUTO ADOLFO LUTZ. Métodos físicos-químicos para análise de alimentos. $4^{\circ} \mathrm{ed}$. Brasília: Ministério da Saúde, Agência Nacional de Vigilância Sanitária, 2008. 1020 p.

JAY, J. M. Microbiologia de alimentos. $6^{\circ}$ ed, Porto Alegre: Artmed, 2005. 711 p.

KRAUTLER, B. Chlorophyll breakdow and chlorophyll catabolites. The porphyrin handbook, New York, v. 13, n. 1, p. 183-209, 2003.

LOPES, R. L. T. Fontes de contaminação de alimentos. Dossiê Técnico. Fundação Centro Tecnológico de Minas Gerais CETEC, 2007. Disponível em:

$<$ http://www.cdt.unb.br/telecentros/appcc/dossie_bpf.pdf>. Acesso em: 4 dez. 2012.

LOURES, N. T. P.; NÓBREGA, L. H. P.; COELHO, S. R. M. Análise físico-química, microbiológica e sensorial de brotos de lentilha da variedade Precoz. Acta Scientiarum Agronomy, Maringá, v. 31, n. 4, p. 599606, 2009.

LUDWIG, M.P., SCHUCH, L.O.B.; LUCCA FILHO, O.A.; AVELAR, S.A.G.; MIELEZRSKI, F.; PANOZZO, L. E.; OLIVIO, M.; SEUS, R. Desempenho de plantas de feijão originadas de lotes de sementes com diferentes níveis de qualidade fisiológica. Revista de Zootecnia, Veterinária e Agronomia, Uruguaiana, v. 15 , n. 2, p. 44-52, 2008.

MACHADO, A. L. L.; BARCELOS, M. F. P.; TEIXEIRA, A. H. R. ; NOGUEIRA, D. A. Avaliação de componentes químicos em brotos de Fabaceae para o consumo humano. Ciência e Agrotecnologia, Lavras, v. 33, n. 4, p. 1072-1078, 2009.

MACHADO, C.M.; FERRUZZI M.G.; NIELSEN, S.S. Impacto of the hard-to-cook phenomenon on phenolic antioxidants in dry beans (Phaseolus vulgaris). Journal of Agricultural and Food Chemistry, Washington DC, v. 56, n. 9, p. 3102-3110, 2008. http://dx.doi.org/10.1021/jf072861y

MAGUIRE, J. D. Speed of germination aid in selection and evaluation for emergence and vigour. Crop Science, Madison, v. 2, n. 2, p. 176-177, 1962. http://dx.doi.org/10.2135/cropsci1962.0011183X000200020033x 
MARTINEZ, A. P. C.; MARTINEZ, P. C. C.; SOUZA, M. C.; BRAZACA, S. G. C. Alterações químicas em grãos de soja com a germinação. Ciência e Tecnologia de Alimentos, Campinas, v. 31, n. 1, p. 23-30, 2011. http://dx.doi.org/10.1590/S0101-20612011000100004

MAYER, A. M.; POLJAKOFF-MAYBER, A. The germination of seeds. 4 ed. Oxford: Pergamon Press, 1989. $403 \mathrm{p}$.

MEILGAARD, M.; CIVILLE, C. V.; CARR, G. Sensory evaluation techniques. 3 ed. London: CRC Press, 1999, $281 \mathrm{p}$.

MERCALI, C. A. Estudo do perfil fitoquímico, nutricional e atividades biológicas do broto de girassol (Helianthus annuus L). Curitiba: UFPR, 2011. 107f. Dissertação (Mestrado em Ciências Farmacêuticas) Universidade Federal do Paraná, Curitiba, 2011.

NÓBREGA, L. H. P. Estresse hídrico na germinação de sementes e no crescimento inicial de plantas de diversas cultivares de soja com determinados níveis de vigor. Jaboticabal: FCAV, UNESP, 1993. 165p. Dissertação (Mestrado em Produção e Tecnologia de Sementes) - Faculdade de Ciências Agrárias e Veterinárias, Universidade Estadual Paulista Júlio de Mesquita Filho, 1993.

RAMIREZ-CARDENASI, L.; LEONEL, A. J. C.; COSTA, N. M. B. Efeito do processamento doméstico sobre o teor de nutrientes e de fatores antinutricionais de diferentes cultivares de feijão comum. Ciência e Tecnologia de Alimentos, Campinas, v. 28, n. 1, p. 200-213, 2008. http://dx.doi.org/10.1590/S010120612008000100029

ROCA, M.; JAMES, C.; PRUZINSKÁ, A.; HORTENSTEINER, S.; THOMAS, H.; OUGHAM, H. Analysis of the chlorophyll catabolism pathway in leaves of an introgression senescence mutant of Lotium Temulentum. Phytochemistry, Kidlington, v. 65, n. 9, p. 231-238, 2004.

SILVA, N. JUNQUEIRA, V. C. A.; SILVEIRA, N. C. de A.; TANIWAKI, M. H.; SANTOS, R. F. S. dos; GOMES, R. A. R. Manual de métodos e análises microbiológicas de alimentos. $3^{\circ}$ ed., São Paulo: Livraria Varela, 2007. $536 \mathrm{p}$.

STONE, H.; SIDEL, J. L. Sensory evaluation practices. New York: Academic Press, 1993. 338 p.

TACO. Tabela brasileira de composição de alimentos / NEPA - UNICAMP.- 4. ed. rev. e ampl.. Campinas: NEPAUNICAMP, 2011.161p. Disponível em:

<http://www.unicamp.br/nepa/taco/>. Acesso em: 20 jan. 2012.

TOLEDO, M. Z.; FONSECA, N. R.; CESAR, M. L.; SORATTO, R. P.; CAVARIANI, C.; CRUSCIOL, C. A. C. Qualidade fisiológica e armazenamento de sementes de feijão em função da aplicação tardia de nitrogênio em cobertura. Pesquisa Agropecuária Tropical, Goiânia, v. 39, n. 2, p. 124-133, 2009.

UNIFEIJÃO. Calendário de plantio e colheita do feijão. Disponível em:

<http://www.unifeijao.com.br/feijao_do_brasil/colheita.php>. Acesso em: 30 dez. 2011.

VELOSO, C. R. Alimentariun: Feijão azuki. Disponível em:

<http://alimentarium.blogspot.com/2010/02/feijao-azuki.html>. Acesso em: 07 nov. 2012.

VIEIRA, R. F.; LOPES, J. D. S. Produção de brotos comestíveis - Feijão moyashi, alfafa, trevo, rabanete e brócolis. Viçosa: CPT, 2001. 108 p.

VIEIRA, R. F.; PAULA JÚNIOR, T. J. de.; JACOB, L. L.; SANTOS, dos J. Desempenho de genótipos de feijão-mungo-verde semeados no inverno na Zona da Mata de Minas Gerais. Revista Ceres, Viçosa, v. 58, n. 3, p. 402-405, 2011.

VIEIRA, R. F.; NISHIHARA, M. K. Comportamento de cultivares de mungo-verde (Vigna radiata) em Viçosa, MG. Revista Ceres, Viçosa, v. 39, n. 221, p. 60-83, 1992. 